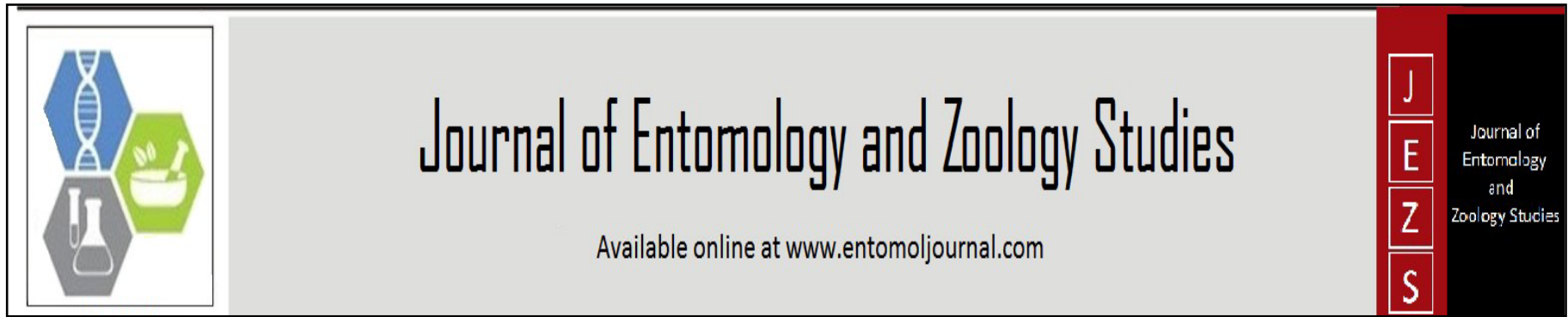

E-ISSN: 2320-7078

P-ISSN: 2349-6800

JEZS 2016; 4(1): 173-174

(C) 2016 JEZS

Received: 14-11-2015

Accepted: 16-12-2015

Mark Ian Cooper

Department of Biological

Sciences, University of Cape

Town, Private Bag X3,

Rondebosch 7701, South Africa.
Correspondence:

Mark Ian Cooper

Department of Biological

Sciences, University of Cape

Town, Private Bag X3,

Rondebosch 7701, South Africa.

\section{Fire millipedes obey the female sooner norm in cross mating Centrobolus (Myriapoda)}

\section{Mark Ian Cooper}

\section{Abstract}

Sexual mediation of copulation duration is reviewed in arthropods. Copulation duration and ejaculate volume were recorded in cross mating Centrobolus to test species' mediation differences. Conspecific C. inscriptus copulation durations were long (170.0 $\pm 49.3 \mathrm{~min}, \mathrm{n}=46)$, C. annulatus copulation durations were short (39.4 $\pm 18.6 \mathrm{~min}, \mathrm{n}=8$ ), while mating between heterospecifics (C. inscriptus X C. annulatus) had the shortest copulation durations $(12.4 \pm 10.6 \mathrm{~min}, \mathrm{n}=6)$; when re-mating interval, sexual size

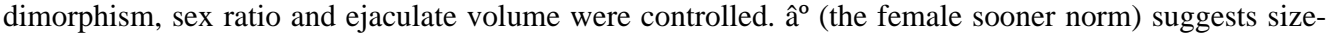
assortative mating without a size based preference in these mate-guarding millipedes.

Keywords: control, copulation, cross, duration, female, male, mate-guarding

\section{Introduction}

Cross-mating experiments can test which sex mediates copulation ${ }^{[1-2]}$. Male mediation of copulation duration is known in the fruitflies Drosophila melanogaster ${ }^{[3-4]}$ and D. montana ${ }^{[5]}$, firefly Photinus macdermotti [6], millipede Alloporus uncinatus [7], mite Macrocheles muscaedomesticae [8], spiders Hogna helluo ${ }^{[9]}$ and Argiope keyserlingi ${ }^{[10]}$, praying mantid Ciulfina ${ }^{2}$, and soldier fly Merosargus cingulatus ${ }^{[11]}$. Female mediation is known only in the millipede Alloporus uncinatus ${ }^{[12]}$.

Numerous species of millipede can coexist in sympatry ${ }^{[13-17]}$. The inscribed red millipede Centrobolus inscriptus and the red ringed millipede C. annulatus exemplify this sympatry ${ }^{[17]}$. They have equal sexual size dimorphism ${ }^{[18]}$, but differ in copulation duration ${ }^{[19]}$ and genital structure ${ }^{[20]}$.

A one-way cross experiment between C. inscriptus and C. annulatus was performed to find changes in mediation of copulation duration.

\section{Materials and Methods}

Data were collected during the rainy seasons (1996-1998) as millipede surface activity is seasonal and related to feeding and reproduction in southern Africa [17, 21-24]. Centrobolus inscriptus (Attems, 1928) and C. annulatus (Attems, 1934) were sampled in coastal forest belt at Twin Streams Farm, Mtunzini (28 $\left.{ }^{\circ} 55^{\prime} S ; 3^{\circ} 45^{\prime} \mathrm{E}\right)$. Live specimens were transported to the laboratory, where unisex groups were housed in plastic containers lined with moist vermiculite (5 mm deep) at $25{ }^{\circ} \mathrm{C}$ temperature; $70 \%$ relative humidity; 12:12 hour light-dark cycle. Fresh vegetables were provided ad libitum. Males and females of both species were placed in glass arenas (30 X 22 X $22 \mathrm{~mm}$ ). Copulation durations were recorded by isolating mating pairs using plastic beakers (13 $\mathrm{cm}$ diameter). The radio isotope labelling technique was used to record and control ejaculate volume ${ }^{[12,25]}$.

\section{Results}

Mating pairs formed within 20 minutes of introducing the males to females. Conspecific $C$. inscriptus copulation durations were long $(170.0 \pm 49.3 \mathrm{~min}, \mathrm{n}=46)$ and $C$. annulatus copulation durations were short (39.4 $\pm 18.6 \mathrm{~min}, \mathrm{n}=8)$. Mating between heterospecifics $(C$. inscriptus X C. annulatus) had even shorter copulation durations $(12.4 \pm 10.6 \mathrm{~min}, \mathrm{n}=6)$. Differences in copulation duration were significant (Mann-Whitney U-test: $Z=2.56, n=8,6$, $\mathrm{P}=0.01$ ). Differences in ejaculate volume were not significant (Mann-Whitney U-test: $\mathrm{Z}=$ $1.23, \mathrm{n}=8,6, \mathrm{P}=0.22$ ). 


\section{Discussion}

Cross-mating in Centrobolus has not been observed in nature. Mating C. inscriptus males with C. annulatus females were created in the laboratory to show copulation duration changed with species when re-mating interval, size, sex ratio and ejaculate volume were controlled. Copulation may be female mediated in C. inscriptus.

The explanation for the reduced copulation duration in the hetero-specific crosses cannot be based on species sexual size preference ${ }^{[18]}$, sex ratio ${ }^{[17]}$ or sperm load ${ }^{[25]}$ as these factors were controlled in the cross mating experiment. It is possible that variation in genital morphologies and loss of genital contact are responsible for the reduced copulation durations ${ }^{[26]}$. Female mediation or loss of female control is suggested as the explanation for reduced copulation durations in the heterospecific cross. If female mediation is species-specific and based on genital contact, then the loss of genital contact following insemination may result in loss of mediation and shorter copulation duration. Further analysis of the variation in the timing of insemination is needed to test whether the genital contact is coupled with insemination and sperm displacement and exclude male control.

\section{Conclusion}

The reduced copulation durations in hetero-specific crosses may be explained by the female sooner norm $\left(\hat{a}^{0}{ }^{[27]}\right.$.

\section{Acknowledgement}

WESSA (Wildlife and Environment Society of Southern Africa) provided their facilities.

\section{References}

1. Friberg U. Male perception of female mating status: its effect on copulation duration, sperm defence and female fitness. Animal Behaviour 2006; 72(6):1259-1268.

2. Holwell GI. Geographic variation in genital morphology of Ciulfina praying mantids. Journal of Zoology. 2008; 276(1):108-114.

3. MacBean IT, Parsons PA. Directional selection for duration of copulation in Drosophila melanogaster. Genetics 1967; 56(2):233-239.

4. Bretman A, Westmancoat JD, Chapman T. Male control of mating duration following exposure to rivals in fruitflies. Journal of Insect Physiology. 2013; 59(8):824827.

5. Mazzi D, Kesäniemi J, Hoikkala A, Klappert K. Sexual conflict over the duration of copulation in Drosophila montana: why is longer better? BMC Evolutionary Biology 2009, 9(132).

6. Wing SR. Prolonged copulation in Photinus macdermotti with comparative notes on Photinus collustrans (Coleoptera: Lampyridae). Florida Entomologist 1985; 68(4):627-634.

7. Telford SR, Dangerfield JM. Males control the duration of copulation in the tropical millipede Alloporus uncinatus (Diplopoda: Julida). South African Journal of Zoology. 1994; 29(4):266-268.

8. Yasui Y. Adaptive control of copulation duration by males under sperm competition in the mite, Macrocheles muscaedomesticae. Experimental and Applied Acarology. 1994; 18(9):543-554.

9. Wilder SM, Rypstra AL. Male Control of Copulation Duration in a Wolf Spider (Araneae: Lycosidae). Behaviour 2007; 144(4):471-484.

10. Herberstein ME, Schneider JM, Harmer AMT, Gaskett AC, Robinson K, Shaddick K et al. Sperm storage and copulation duration in a sexually cannibalistic spider. Journal of Ethology. 2011; 29(1):9-15.

11. Barbosa F. Copulation duration in the soldier fly: the roles of cryptic male choice and sperm competition risk. Behavioral Ecology 2011; 22(6):1332-1336.

12. Barnett M, Telford SR. The timing of insemination and its implications for sperm competition in a millipede with prolonged copulation. Animal Behaviour 1994; 48(2):482484.

13. Greyling MD, Van Aarde RJ, Ferreira SM. Seasonal changes in habitat preferences of two closely related millipede species. African Journal of Ecology. 2001; 39(1):51-58.

14. Smit A-M, Van Aarde RJ. The influence of millipedes on selected soil elements: a microcosm study of three millipede species of coastal sand dunes. Functional Ecology 2001; 15(1):51-59.

15. Redi BH, Van Aarde RJ, Wassenaar TD. Coastal dune forest development and the regeneration of millipede communities. Restoration Ecology 2005; 13(2):283-290.

16. Tanabe T, Sota T. Complex Copulatory Behaviour and the Proximal Effect of Genital and Differences on Mechanical Reproductive Isolation in the Millipede Genus Parafontaria. American Naturalist 2008; 171(5):692-699.

17. Cooper MI. Sex ratios, mating frequencies and relative abundance of sympatric millipedes in the genus Chersastus (Diplopoda: Pachybolidae). Arthropods 2014a; 3(4):174-176.

18. Cooper MI. Sexual size dimorphism and corroboration of Rensch's rule in Chersastus millipedes (Diplopoda: Pachybolidae). Journal of Entomology and Zoology Studies. 2014b; 2(6):264-266.

19. Cooper MI, Telford SR. Copulatory Sequences and Sexual Struggles in Millipedes. Journal of Insect Behaviour. 2000; 13(3):217-230.

20. Cooper MI. Elaborate gonopods in the myriapod genus Chersastus (Diplopoda: Trigoniulidae). Journal of Entomology and Zoology Studies 2015b; 3(4):235-238.

21. Dangerfield JM. Ingestion of mineral soil/litter mixtures and faecal pellet production in the southern African millipede Alloporus uncinatus (Attems). Pedobiologia 1993; 37(3):159-166.

22. Dangerfield JM, Telford SR. Are millipedes important for soil fertility? The Zimbabwean Science News 1989; 23:66-68.

23. Dangerfield JM, Telford SR. Seasonal activity patterns of julid millipedes in Zimbabwe. Journal of Tropical Ecology. 1991; 7(2):281-285.

24. Mwabvu T. Surface-active millipedes (Diplopoda) and associated mites (Acaridae: Mesostigmata) in Pigeon Valley Nature Reserve in Durban, South Africa. Soil Organisms 2014; 86(2):147-151.

25. Cooper MI. Competition affected by re-mating interval in a myriapod. Journal of Entomology and Zoology Studies. 2015a; 3(3):77-78.

26. Rondeau A, Sainte-Marie B. Variable Mate-Guarding Time and Sperm Allocation by Male Snow Crabs (Chionoecetes opilio) in Response to Sexual Competition, and their Impact on the Mating Success of Females. The Biological Bulletin 2015; 201(2):204-217.

27. Galipaud M, Bollache L, Dechaume-Moncharmont F-X. Assortative mating by size without a size-based preference: the female-sooner norm as a mate-guarding criterion. Animal Behaviour 2013; 85(1):35-41. 